\title{
IMPLEMENTASI ISM CODE PADA KAPAL KAPAL DI PELABUHAN TANJUNG PERAK
}

\author{
Anak Agung Istri Sri Wahyuni ${ }^{1^{*}}$, Maulidiah Rahmawati ${ }^{1}$, Siti Fatimah $\mathbf{M}^{1}$ \\ ${ }^{1}$ Jurusan Nautika, Politeknik Pelayaran Surabaya \\ email: deryaagung02@yahoo.com
}

diterima tanggal : 15 Maret 2018 disetujui tanggal : 10 Mei 2018

\section{Abstrak}

Banyaknya kasus kecelakaan kapal merupakan salah satu indikasi perlunya perbaikan dalam sistem transportasi laut. Berdasarkan laporan hasil investigasi KNKT pada kurun waktu tahun 2007 sampai dengan tahun 2014 pada wilayah perairan di Indonesia, terjadi kecelakaan kapal dengan berbagai jenis kejadian seperti tenggelam, terguling, kandas dan tubrukan. Dari hasil investigasi KNKT, didapatkan kesimpulan terkait dengan faktor penyebab serta faktor yang berkontribusi, diantaranya kelalaian manusia (human error), teknis dan cuaca. Penelitian ini dimaksudkan untuk mengetahui bagaimana Implementasi ISM Code yang dilakukan di kapal kapal di Pelabuhan Tanjung Perak dan tingkat pengetahuan kru tentang ISM Code. Data yang digunakan dalam penelitian ini adalah data primer berupa kuisioner yang digunakn untuk mengukur tingkat pemahaman officer tentang ISM Code dan pengimplementasian diatas kapal serta mengukur tingkat pengetahuan kru tentang ISM Code. Berdasarkan hasil analisis korespondensi dengan analisis Importance-Performance (Kepentingan Kinerja) diperoleh hasil berupa diagram dengan hasil penelitian Implementasi ISM Code pada kapalkapal di Pelabuhan Tanjung Perak menunjukkan bahwa terdapat faktor-faktor yang perlu mendapatkan perhatian dan peningkatan yaitu pelaksanaan drill/latihan untuk semua personil kapal dalam menunjang pelaksanaan SMS dan sistem pemeliharaan berencana yang mencakup prosedur pemeliharaan untuk semua bagian dari sistem. Implementasi ISM Code yang diamati dari pemahaman Officer menunjukkan bahwa secara umum termasuk dalam kategori baik, dimana sebanyak 77,33\% responden memberikan jawaban dengan benar. Serta tingkat pemahaman dan pengetahuan crew tentang ISM Code termasuk dalam kategori kurang dimana terdapat 54,23\% responden dapat memberikan jawaban dengan tepat.

Kata kunci : ISM Code, analisis Importance-Performance

\begin{abstract}
One of the indication which has to be mended in marine transportation industry is there are many ship accident cases. Based on the report of the investigation result of KNKT during the period of 2007 until year 2014 in Indonesian sailing area, ship accidents happened with various types of incidents such as drowning, rolling, crashing and collision. From the result of KNKT investigation, It can be concluded to casual factors and contributing factors, including human error, technical system and weather. This research is intended to figure out the implementation of ISM Code conducted on board ship at Tanjung Perak Port and level of the crew knowledge about ISM Code. The data used in this study is primary data in the form of questionnaires in order to measure the level of officer's understanding of the ISM Code and implementation on board and measure the knowledge level of the crew about the ISM Code. Based on the result of correspondence analysis with the analysis of Importance-Performance (Interests - Performance) obtained results of research Implementation of ISM Code on the ships at the Tanjung Perak Port showed that there are factors that need to get attention and improvement that is the implementation of drill / all ship personnel in support of the implementation of SMS and maintenance planning system which includes maintenance procedures for all parts of the system. The Implementation of the observed ISM Code from the Officer's understanding indicates that generally included in the good category, where as many as $77.33 \%$ of respondents got the right answer. And the level of understanding and knowledge of the crew about the ISM Code included in the less category where there are $54.23 \%$ of respondents can provide the right answers.
\end{abstract}

Keyword : ISM Code, Importance-Performance Analysis 


\section{Latar Belakang}

Pelayaran perlu lebih dikembangkan potensinya dan ditingkatan peranannya baik nasional maupun internasional sebagai penunjang, pendorong dan penggerak pembangunan nasional demi peningkatan kesejahteraan rakyat. Sebagai salah satu model transportasi, maka pelayaran bagi Negara Republik Indonesia yang merupakan negara kepulauan, tidak dapat dipisahkan dari model model transportasi lain, perlu ditata dalam sistem transportasi nasional yang dinamis dan mampu mengadaptasi kemajuan di masa depan.

Ketentuan dasar mengenai pelayaran tersebut telah diatur dalam UU No 17 Tahun 2008 tentang pelayaran nasional. Salah satu isi dari pasal - pasal UU No. 17 Tahun 2008 tentang pelayaran adalah keselamatan pelayaran. Keselamatan pelayaran yang dimaksud adalah kelaiklautan kapal[1]

Secara keseluruhan termasuk di dalam pasal 1 ayat 32 sampai ayat $44 \mathrm{UU}$ no. 17 Tahun 2008, sementara pasal 1 ayat 34 khusus berisi keselamatan kapal yaitu keadaan kapal yang memenuhi persyaratan material, konstruksi, bangunan, permesinan dan perlistrikan, stabilitas, tata susunan serta perlengkapan termasuk perlengkapan alat penolong dan radio, elektronik kapal, yang dibuktikan dengan sertifikat setelah dilakukan pemeriksaan dan pengujian [1].
Keselamatan pelayaran tidak hanya ditentukan oleh satu faktor, misalnya kecanggihan kapal dan peralatan-peralatan modern yang melengkapinya, namun juga sangat tergantung kepada berbagai faktor, seperti sumber daya manusia, peralatan di darat, koordinasi yang dilaksanakan selama sebelum dan selama pelayaran berlangsung serta memperhitungkan rambu-rambu laut dan factor penumpang sangat berperan untuk mewujudkan hal tersebut[2].

Dari sekian banyak faktor, dan penyelidikan IMO diketahui terjadinya kecelakaan $80 \%$ disebabkan oleh faktor manusia dan $20 \%$ oleh kapal itu sendiri, sehingga diperlukan aturan-aturan yang baku agar dapat dijadikan pedoman dan acuan terhadap aktivitas dan tindakan pelayanan di Lautan [3]. Dari pernyatakan tersebut bahwa kecelakaan sering terjadi karena faktor manusia dan manajemen serta organisasi yang belum sepenuhny memberi dukungan atas kebutuhan operasional kapal yang aman dan pencegahana pencemaran laut

Berdasarkan hal-hal tersebut diatas, maka IMO (International Maritime Organization) mengeluarkan peraturan yakni ISM Code (International Safety Management Code) sebagai alat untuk menstandarkan "Safe Management for Operation of Ships and Pollution Prevention" yang terdapat di dalam SOLAS 1974 (Safety of

Tabel 1. Laporan kecelakan kapal KNKT tahun 2010 - Tahun 2016

\begin{tabular}{|c|c|c|c|c|c|c|c|c|c|c|}
\hline \multirow[b]{3}{*}{ No. } & \multicolumn{10}{|c|}{$\begin{array}{l}\text { DATA INVESTIGASI KECELAKAAN PELAYARAN - KNKT } \\
\text { TAHUN 2010-2016 }\end{array}$} \\
\hline & \multirow[b]{2}{*}{ TAHUN } & \multirow[b]{2}{*}{$\begin{array}{l}\text { JUMLAH } \\
\text { KECELAKAAN }\end{array}$} & \multicolumn{5}{|c|}{ JENIS KECELAKAAN } & \multicolumn{2}{|c|}{ KORBAN JIWA } & \multirow[b]{2}{*}{ REKOMENDAS } \\
\hline & & & TENGGELAM & \begin{tabular}{|c|} 
TERBAKAR/ \\
MELEDAK
\end{tabular} & TUBRUKAN & KANDAS & LAIN-LAIN & $\begin{array}{c}\text { KORBAN } \\
\text { MENINGGAL/ } \\
\text { HILANG } \\
\end{array}$ & $\begin{array}{l}\text { KORBAN } \\
\text { LUKA-LUKA }\end{array}$ & \\
\hline 1 & 2010 & 5 & 1 & 1 & 3 & 0 & 0 & 15 & 85 & 45 \\
\hline 2 & 2011 & 6 & 1 & 3 & 2 & 0 & 0 & 86 & 346 & 82 \\
\hline 3 & 2012 & 4 & 0 & 2 & 2 & 0 & 0 & 13 & 10 & 28 \\
\hline 4 & 2013 & 6 & 2 & 2 & 2 & 0 & 0 & 65 & 9 & 47 \\
\hline 5 & 2014 & 7 & 2 & 3 & 2 & 0 & 0 & 22 & 4 & 25 \\
\hline 6 & 2015 & 11 & 3 & 4 & 3 & 1 & 0 & 85 & 2 & 11 \\
\hline 7 & 2016 & 15 & 4 & 4 & 3 & 2 & 2 & 51 & 18 & 35 \\
\hline \multicolumn{2}{|c|}{ TOTAL } & 54 & 13 & 19 & 17 & 3 & 2 & 337 & 474 & 273 \\
\hline
\end{tabular}

Sumber : KNKT 2016 
Life at Sea) Bab IX, yaitu : Management for the Safe Operation Of Ships[4].

Tanpa menerapkan aturan-aturan dan kebijakan baku di bidang pelayaran mengenai keselamatan pelayaran, tujuan untuk mewujudkan keselamatan pelayaran tidak akan dapat diwujudkan dengan baik. Untuk itu di Indonesia telah dilakukan ratifikasi terhadap aturan-aturan internasional menyangkut keselamatan pelayaran dengan mengeluarkan keputusan Presiden. Adanya proses ratifikasi tersebut, pemerintah Indonesia memperoleh mandat untuk menerapkan aturanaturan Internasional dan karenanya pemerintah harus menjamin dan bertanggung jawab [5].

Dalam kaitannya dengan keselamatan pelayaran, pemerintah menyampaikan pemberitahuan kepada Organisasi Internasional Maritim (IMO) yang menyatakan bahwa "untuk urusan yang berhubungan dengan penerapan aturan internasional tentang keselamatan pelayaran oleh pemerintah Indonesia, ditunjuk Direktorat Jenderal Perhubungan Laut sebagai “administrator". Selanjutnya IMO mengakui dan mengumumkan kepada seluruh negara anggotanya bahwa "administration" untuk implementasi ketentuan internasional mengenai keselamatan pelayaran di Indonesia adalah Direktorat Jenderal Perhubungan Laut.

Salah satu tugas pokok Direktorat Jenderal Perhubungan Laut adalah merupakan pembinaan keselamatan pelayaran laut dan perlindungan lingkungan dan bahaya pencemaran yang bersumber dari kapal, serta sebagai "Administration" harus mampu menjamin dan

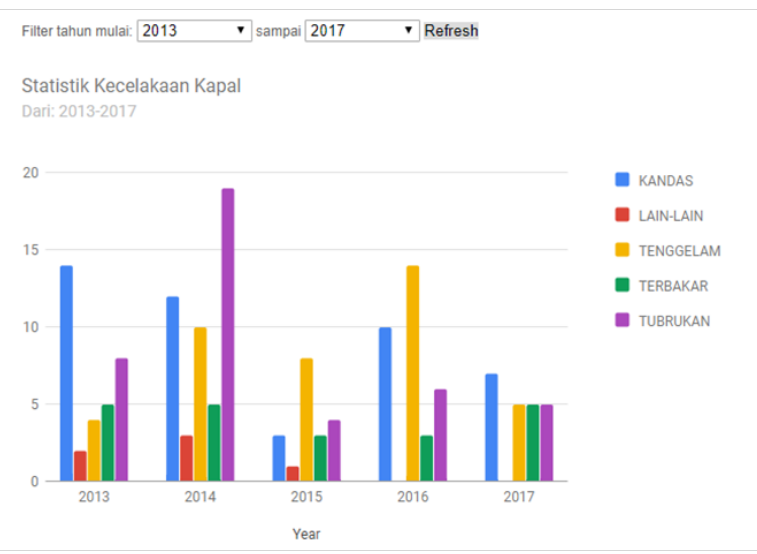

Gambar 1. Statistik Kecelakan kapal Mahkamah Pelayaran tahun 2013 - Tahun 2017 bertanggung jawab bagi pelaksaanaan aturan internasional tentang keselamatan pelayaran di seluruh perairan Indonesia.

Berdasarkan data yang peneliti peroleh dari Media Release KNKT sepanjang tahun 2010 sampai tahun 2016 telah terjadi sekitar 54 kasus kecelakaan yang menelan cukup banyak korban jiwa. Kondisi ini menunjukkan bahwa masih terdapat kelemahan dalam pelaksanaan pengawasan pelayaran. Untuk lebih jelas lihat pada Tabel 1.

Selain berdasar dari data KNKT peneliti juga memperoleh data dari Mahkamah Pelayaran Kementerian Perhubungan terkait Statistik Kecelakaan Kapal dalam rentang waktu Tahun 2013 sampai dengan 2017 dimana pada data statistik kasus Kecelakaan oleh Mahkamah Pelayaran sudah terlihat penurunan kasus kecelakaan kapal untuk tahun 2017 , peningkatan hanya terjadi pada kecelakaan kapal pada kapal yang terbakar

Berdasarkan data dari KNKT dan Mahkamah Pelayaran tentang kecelakaan kapal berikut peneliti melakukan pendataan kecelakaan kapal yang terjadi di Pelabuhan Tanjung Perak Surabaya dalam kurun rentang waktu tahun 2014 sampai dengan 2017 dimana terdapat 6 kasus kecelakan kapal.

Tabel 2. Data Kecelakaan Kapal di Pelabuhan Tanjung Perak Surabaya

\begin{tabular}{|l|l|l|l|}
\hline NO & $\begin{array}{l}\text { Jenis Ke- } \\
\text { celakaan }\end{array}$ & Tahun & \multicolumn{1}{|c|}{ Keterangan } \\
\hline 1. & Tubrukan & 2014 & $\begin{array}{l}\text { Tubrukan antara KM. } \\
\text { Journey dengan KM. } \\
\text { Fatima III dan KM. } \\
\text { Lambelu di sekitar } \\
\text { Bouy 10 alur Pelayaran } \\
\text { Pelabuhan Tanjung Perak } \\
\text { Surabaya }\end{array}$ \\
\hline 2. & Tenggelam & 2015 & $\begin{array}{l}\text { Kecelakaan Kapal } \\
\text { Tenggelamnya KM. } \\
\text { Pertama I di Wilayah } \\
\text { Perairan Bandar } \\
\text { Pelabuhan Gresik Pada } \\
\text { Posisi disebelah Timur } \\
\text { Alur Pelayaran Barat } \\
\text { Surabaya }\end{array}$ \\
\hline 3. & Tenggelam & 2016 & $\begin{array}{l}\text { Kecelakaan Kapal } \\
\text { Tenggelamnya KM } \\
\text { MeratusBanjar 2 di Laut } \\
\text { Jawa Timur Laut Pulau } \\
\text { Madura }\end{array}$ \\
\hline
\end{tabular}




\begin{tabular}{|l|l|l|l|}
\hline 4. & Tubrukan & 2016 & $\begin{array}{l}\text { Kecelakaan Kapal } \\
\text { Tubrukan antara KM. } \\
\text { Wihan Sejahtera dengan } \\
\text { Pile Frame Bagian } \\
\text { dari DBD. CAI JUN } \\
\text { 1 di Perairan Bandar } \\
\text { Pelabuhan Tanjung Perak }\end{array}$ \\
\hline 5. & Tubrukan & 2016 & $\begin{array}{l}\text { Kecelakaan Kapal } \\
\text { Tubrukan antar AMT. } \\
\text { Navigator Aries dengan } \\
\text { MV. Leo Perdana diantara } \\
\text { Bouy Nomor 6 dan Bouy } \\
\text { Nomor 11 alur Pelayaran } \\
\text { Barat Pelabuhan Tanjung } \\
\text { Perak Surabaya }\end{array}$ \\
\hline 6. & Terbakar & 2017 & $\begin{array}{l}\text { Kecelakaan kapal } \\
\text { Terbakarnya KM. New } \\
\text { Glory di Perairan Bandar } \\
\text { Pelabuhan Tanjung Perak } \\
\text { Surabaya }\end{array}$ \\
\hline
\end{tabular}

Sumber : KNKT \& Mahmakah Pelayaran 2017

Berdasarkan data yang diperoleh bahwa hasil investigasi dari kecelakaan yang terjadi khusunya kecelakaan Kapal pada pelabuhan Tanjung Perak Surabaya diindikasi bahwa salah satu penyebab sehingga masih terjadi kecelakaan-kecelakaan pelayaran adalah kurang diimplementasikannya ISM Code dengan berbagai ketentuannya, disamping itu juga kurangnya pengawasan terhadap kapal-kapal, sehingga kelaiklautan kapal tidak terpantau dengan baik.

Sumber Daya Manusia (SDM) sebagai pelaksana pengawasan keselamatan pelayaran di Pelabuhan harus bekerja dengan baik sesuai dengan tugas di bidang pelayaran, sehingga para nahkoda juga dapat mengimplementasikan ISM Code pada kapal-kapal mereka[6].

Penyediaan sarana dan prasaran kantor maupun sarana dan prasaran pengawasan untuk pemeriksaan di kapal-kapal juga disesuaikan dengan kebutuhan sehingga pengawasan dapat berjalan dengan baik. Kondisi tersebut mempengaruhi upaya untuk mewujudkan keselamatan pelayanan yang diharapkan sehingga perlu tindakan-tindakan yang lebih nyata untuk menanggulangi permasalahan-permasalahan yang timbul agar keselamatan pelayaran dapat terjamin.

\section{METODE PENELITIAN}

A. Desain Penelitian

Penelitian ini menggunakan metode penelitian deskriptif kuantitatif yang akan menggambarkan secara sistematis bagaimana pengimplementasian ISM Code diatas kapal dan mengukur tingkat pemahaman dan pengetahuan crew kapal tentang ISM Code

B. Variabel Variabel Penelitian dan Definisi Operasional

Berdasarkan kerangka pikir pada bagian terdahulu, maka definsi operasional variabel adalah :

Implementasi, yaitu penerapan strategi yang cocok untuk memperoleh hasil yang obyektif dalam penerapan ISM Code diatas kapal

\section{Populasi dan Sampel/Subjek Penelitian}

1. Populasi Penelitian

Populasi yang dimaksud dalam penelitian ini adalah awak kapal dari kapal yang berlayar di wilayah perairan Indonesia yang sedang sandar di pelabuhan Tanjung Perak Surabaya.

\section{Sampel Penelitian}

Penentuan sampel dilakukan dengan Teknik pengambilan sampel non probability sampling dengan menggunakan purposive sampling. Purposive sampling adalah teknik penentuan sampel dengan pertimbangan tertentu. Sehubungan dengan pertimbangan tersebut teknik tersebut digunakan untuk menetapkan besarnya sampel dari kapal - kapal yang sandar di Pelabuhan Tanjung Perak yaitu sebanyak 12 kapal yang kami gunakan sebagai sampel penelitian ini

\section{Lokasi Penelitian}

Penelitian ini dilaksanakan pada di Pelabuhan Tanjung Perak Propinsi Jawa Timur, dimana pada pelabuhan inilah pengawasan dilaksanakan baik pengawasan adminstratif maupun pengawasan teknik termasuk pada pengawasan implementasi ISM Code pada kapal-kapal yang sandar di pelabuhan Tanjung 
Perak Surabaya

E. Teknik Pengumpulan Data dan Instrumen Penelitian

Adapun teknik pengumpulan data dalam penelitian ini yakni :

1. Kuesioner yang digunakan adalah kuesioner tertutup, karena jawaban dalam kuesioner sudah disediakan sehingga responden tinggal memilih jawaban yang dikehendaki. Skala pengukuran yang digunakan adalah skala model Likert. Skala model Likert digunakan untuk mengukur sikap, pendapat, dan persepsi seseorang atau sekelompok orang tentang fenomena sosial atau disebut sebagai variabel penelitian. Skor yang digunakan dalam skala model Likert adalah $1-5$. Kuesioner ini untuk mengetahui implementasi ISM Code pada kapal-kapal yang sandar di pelabuhan Tanjung Perak dan juga untuk mengukur tingkat pemahaman dan pengetahuan crew kapal tentang ISM Code

2. Dokumentasi dilakukan untuk mengumpulkan data sekunder.

\section{F. Teknik Analisis Data}

Dari data penelitian yang terkumpul, selanjutnya dianalisis dengan menggunakan teknik analisis deksriptif kuantitatif. Teknik ini dimaksudkan untuk menggambarkan implementasi ISM Code pada kapal-kapal yang sandar di pelabuhan Tanjung Perak dan juga untuk mengukur tingkat pemahaman dan pengetahuan crew kapal tentang ISM Code

Analisis Importance-Performance (Kepentingan - Kinerja) pertama kali digunakan sebagai sarana untuk mengukur kepuasan klien dengan produk atau jasa. Analisis Importance-Performance merupakan suatu metode analisis yang merupakan kombinasi antara aspek-aspek tingkat kepentingan dan kinerja terhadap kualitas atau kondisi suatu objek dalam bentuk dua dimensi. Dua dimensi tersebut dinyatakan dalam suatu Diagram Cartesius yang terdiri dari sepasang sumbu koordinat, di mana sumbu Y menyatakan ukuran Importance (kepentingan) dan sumbu $\mathrm{X}$ menyatakan ukuran Performance (Kinerja) dari unsurunsur yang terlibat dalam pelayanan akan dibandingkan. Ukuran Importance (kepentingan) dan Performance (kinerja) didapatkan dari rata-rata pada setiap atribut menggunakan formula sebagai berikut:

$$
\begin{gathered}
\overline{X i}=\frac{\sum_{i=1}^{k} X}{n} \\
\bar{Y} i=\frac{\sum_{i=1}^{k} Y}{n}
\end{gathered}
$$

dimana:

$\overline{X i}=$ Bobot rata-rata tingkat penilaian kinerja atribut ke-i

$\bar{Y} i=$ Bobot rata-rata tingkat penilaian kepentingan atribut ke-i

$\mathrm{n}=$ Jumlah responden

Bobot untuk setiap atribut pada Importance (kepentingan) dan Performance (kinerja) didapatkan dari hasil pengolahan kuesioner dari para responden. Penilaian kepentingan dan kinerja dari responden dibuat dalam bentuk persepsi menggunakan skala Likert dengan lima tingkat penilaian. Berdasarkan hasil pembobotan pada Importance (kepentingan) dan Performance (kinerja), maka dapat digambarkan dalam suatu diagram Cartesius.

Diagram Cartesius hasil Analisis ImportancePerformance ditunjukkan oleh Gambar 3.

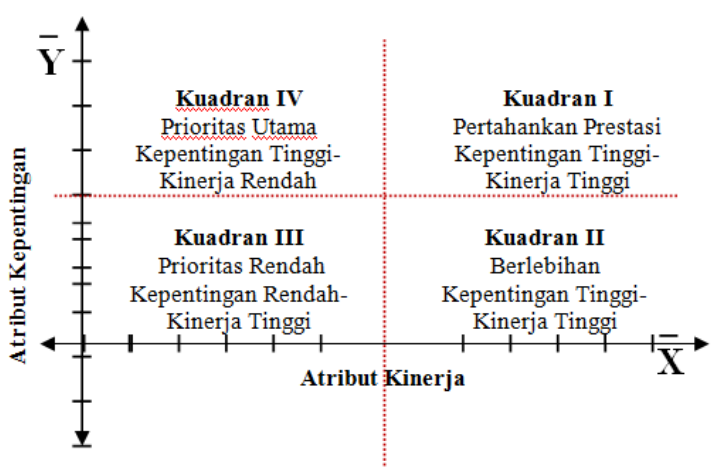

Gambar. 3 Diagram Cartesius Analisis Importance-Performance

Setiap kuadran menggabungkan kepentingan dan kinerja yang ditetapkan oleh elemen pengguna tertentu dari layanan dan memiliki 
nilai yang berbeda dimana data atribut kinerja merupakan nilai dasar dari ini matriks Analisis Importance-Performance.

Model Analisis Importance-Performance dua dimensi dibagi menjadi empat kuadran dengan kinerja pada sumbu $\mathrm{x}$ dan kepentingan pada sumbu y. Masing-masing kuadran menunjukkan strategi yang berbeda.

1. Kuadran I memiliki makna kepentingan tinggi kinerja rendah, sehingga atribut yang masuk dalam kuadran ini mewakili bidang utama yang perlu ditingkatkan dengan prioritas utama, membutuhkan perhatian segera untuk perbaikan dan menunjukkan kelemahan;

2. Kuadran II memiliki makna kepentingan tinggi kinerja tinggi diberi sehingga atribut yang masuk dalam kuadran ini merupakan kekuatan dan pilar organisasi, mengindikasikan peluang untuk mencapai atau mempertahankan keunggulan kompetitif dan kekuatan utama;

3. Kuadran III memiliki makna Kepentingan rendah Kinerja rendah diberi label Prioritas Rendah. Dengan demikian, salah satu atribut yang jatuh ke dalam kuadran ini tidak penting dan tidak menimbulkan ancaman bagi organisasi, kelemahan minor dan tidak memerlukan upaya tambahan.

4. Kuadran IV memiliki makna Kepentingan rendah Kinerja Tinggi, dimana menunjuk kan atribut yang terlalu ditekankan oleh organisasi namun tidak terlalu penting bagi pengguna jasa, menunjukkan bahwa sumber daya suatu atribut berlebihan dan perlu dialihkan atau dialokasikan di tempat lain, misalnya pada Kuadran I.

Selain menggunakan analisis kuadran, untuk mengetahui tingkat pemahaman responden dilakukan melalui perhitungan persentase dari jumlah responden yang dapat memberikan jawaban secara tepat. Kategori persentase untuk pemahaman responden dapat dinyatakan sebagai berikut (menurut Arikunto): a. Kategori baik bila responden dapat menjawab 76 - 100\% dengan benar dari total jawaban pertanyaan

b. Kategori cukup bila responden dapat menjawab $56-75 \%$ dengan benar dari total jawaban pertanyaan

c. Kategori kurang bila responden dapat menjawab $\leq 55 \%$ dengan benar dari total jawaban pertanyaan

\section{HASIL DAN PEMBAHASAN}

A. Implementasi ISM Code

Keselamatan transportasi terwujud dari penyelenggaraan transportasi yang lancar sesuai dengan proseduroperasi dan persyaratan kelaikan teknis terhadap sarana dan prasarana beserta penunjangnya. Faktor manusia merupakan penyebab utama terjadinya kecelakaan selain factor - factor lainnya. Hal tersebut terjadi karena sistem manajemen yang kurang baik, baik system manajemen diatas kapal maupun manajemen perusahaan. Untuk mengurangi kecelakaan dan pencemaran laut yang disebabkan oleh factor manusia maka diperlukan system manajemen keselamatan yang bersinergi antara perusahaan dan kapal. Maka dari pada itu penerapan ISM Code harus dijalankan secara maksimal untuk mencapai keselamatan pelayaran dapan pengoperasian kapal. ISM Code merupakan suatu standar internasional untuk sistem manajemen keselamatan yang bertujuan untuk menjamin bahwa perusahaan memberi pelayanan yang memenuhi persyaratan yang ditetapkan yaitu kapal dapat beroperasi secara aman dan mencegah pencemaran lingkungan. Penerapan ISM Code bagi perusahaan digunakan untuk memperbaiki sistem kerja, untuk menerapkan sistem manajemen keselamatan yang diakui secara internasional, untuk kesiapan menghadapi persaingan pasar, untuk meningkatkan kepercayaan pelanggan terhadap keamanan muatan, dan untuk memuaskan pelanggan[7]. 
1). Perbandingan Kinerja dan Kepentingan Penerapan ISM Code diatas Kapal

Dalam penelitian ini indikator yang mewakili variabel tingkat implementasi

ISM Code dibatasi pada:

1. Kesesuaian dokumen; Kru kapal memahami dokumen-dokumen apa saja yang harus ada di perusahaan dan di kapal dalam menunjang keselamatan kapal.

2. Sasaran manajemen keselamatan di perusahaan; Setiap perusahaan pelayaran memiliki sistem manajemen yang sesuai dengan ISM Code dalam melakukan kegiatan operasional kapal.

3. Sumber daya dan personil; Perusahaan harus memiliki kualifikasi (berkualitas, bersertifikat dan sehat) dalam menunjuk kru kapal sesuai dengan jabatan yang dibutuhkan. Kru kapal juga harus memahami tugas dan tanggung jawab dan melaksanakannya di atas kapal.

4. Pemeliharaan kapal dan peralatannya; Kapal dan seluruh peralatannya harus dipelihara agar selalu dalam kondisi yang baik. Kru kapal harus selalu mengikuti aturan dan regulasi yang berlaku.

Survei implementasi ISM Code terdiri dari 20 butir pernyataan yang meliputi 4 aspek, yaitu kebijakan perusahaan, sumber daya dan personel yang berkualifikasi dan bersertifikat, perawatan dan perbaikan yang berkelanjutan serta kelengkapan dokumen kapal.

Dalam survei keselamatan kapal, ditampilkan nilai rata-rata kondisi dan harapan sebagai alat ukur yang digunakan untuk mengetahui tingkat kinerja dan kepentingan antara persepsi pengguna/pelaku aktifitas berdasarkan kondisi yang ada dibandingkan dengan tingkat harapannya. Analisis importanceperformance dilakukan untuk menyusun ranking dari berbagai elemen dari aspekaspek dan mengidentifikasi tindakan yang diperlukan. Analisis importance-performance menggunakan analisis kuadran yang berfungsi untuk menunjukkan hubungan persepsi atau penilaian antara tingkat kinerja (performance) dan tingkat kepentingan (importance). Penilaian pada kinerja yang menggambarkan kondisi dan tingkat kepentingan yang menunjukkan harapan dilakukan pada skala bernilai 1 sampai dengan 5 . Pada kinerja (performance), skala 1 mewakili pernyataan sangat tidak setuju sampai dengan sangat setuju yang bernilai 5. Hal yang sama juga berlaku pada skala kepentingan (importance) yang dimulai dari sangat tidak penting sampai dengan sangat penting. Hasil analisis importance-performance antara kondisi dan harapan terhadap keselamatan kapal dalam penerapan ISM Code ditunjukkan melalui Tabel. 3

Tabel.3 Implementasi ISM Code

\begin{tabular}{|c|c|c|c|c|}
\hline \multirow{2}{*}{ No. } & \multirow{2}{*}{ Uraian } & \multicolumn{2}{|c|}{ Rata-rata } & \multirow{2}{*}{$\begin{array}{l}\text { Tingkat } \\
\text { kesesuaian } \\
(\%)\end{array}$} \\
\hline & & Kinerja & Kepentingan & \\
\hline \multicolumn{5}{|c|}{ Kebijakan Perusahaan } \\
\hline 1 & $\begin{array}{l}\text { Kapal melaporkan kepada perusahaan mengenai } \\
\text { keabsahan masa berlaku semua sertifikat dan } \\
\text { dokumen yang diperlukan dalam pengoperasian } \\
\text { kapal. }\end{array}$ & 4,65 & 4.79 & 97.14 \\
\hline 2 & $\begin{array}{l}\text { Kapal melakukan prosedur untuk menjamin } \\
\text { lingkungan kerja yang aman dalam pengoperasian } \\
\text { kapal. }\end{array}$ & 4,62 & 4.69 & 98.53 \\
\hline 3 & $\begin{array}{l}\text { Kapal melakukan prosedur untuk persiapan } \\
\text { menghadapi dan menanggulangi keadaan darurat. }\end{array}$ & 4,65 & 4.60 & 101.16 \\
\hline 4 & $\begin{array}{l}\text { Perusahaan membuat kebijakan mengenai } \\
\text { keselamatan dan perlindungan lingkungan. }\end{array}$ & 4,51 & 4.52 & 99.77 \\
\hline
\end{tabular}




\begin{tabular}{|c|c|c|c|c|}
\hline \multirow{2}{*}{ No. } & \multirow{2}{*}{ Uraian } & \multicolumn{2}{|c|}{ Rata-rata } & \multirow{2}{*}{$\begin{array}{l}\text { Tingkat } \\
\text { kesesuaian } \\
(\%)\end{array}$} \\
\hline & & Kinerja & Kepentingan & \\
\hline 5 & $\begin{array}{l}\text { Perusahaan melakukan pengawasan berupa audit } \\
\text { mengenai sistem manajemen keselamatan di atas } \\
\text { kapal. }\end{array}$ & 4,54 & 4.57 & 99.32 \\
\hline \multicolumn{5}{|c|}{ Sumber daya dan Personil yang Berkualifikasi dan Bersertifikat } \\
\hline 6 & $\begin{array}{l}\text { Perusahaan merekrut/memilih kru kapal yang } \\
\text { berkualifikasi, bersertifikat dan sehat secara medis } \\
\text { untuk dipekerjakan di atas kapal. }\end{array}$ & 4,43 & 4.38 & 101.18 \\
\hline 7 & $\begin{array}{l}\text { Seluruh perwira dan ABK diberi waktu yang cukup } \\
\text { untuk menyesuaikan dengan tugas-tugasnya, } \\
\text { dalam hal ini pengenalan terhadap kapal, sijil, dan } \\
\text { perlengkapan darurat. }\end{array}$ & 4,49 & 4.52 & 99.17 \\
\hline 8 & $\begin{array}{l}\text { Kapal mendokumentasikan, bahwa seluruh ABK } \\
\text { telah menerima pengenalan dan penyuluhan serta } \\
\text { mengerti dengan baik terhadap tugas-tugasnya. }\end{array}$ & 4,54 & 4.69 & 96.80 \\
\hline 9 & $\begin{array}{l}\text { Kapal melakukan drill/latihan untuk semua personil } \\
\text { kapal dalam menunjang pelaksanaan SMS. }\end{array}$ & 4,30 & 4.50 & 95.50 \\
\hline 10 & $\begin{array}{l}\text { Seluruh personil kapal berkomunikasi secara efektif } \\
\text { sesuai dengan bahasa yang dapat dimengerti oleh } \\
\text { mereka dan melaksanakan tugas yang berhubungan } \\
\text { dengan SMS dengan penuh tanggung jawab. }\end{array}$ & 4,30 & 4.31 & 99.72 \\
\hline \multicolumn{5}{|c|}{ Perawatan dan Perbaikan yang Berkelanjutan } \\
\hline 11 & $\begin{array}{l}\text { Perusahaan membuat prosedur yang menjamin agar } \\
\text { kapal dapat terpelihara sesuai dengan ketentuan } \\
\text { peraturan yang berlaku. }\end{array}$ & 4,32 & 4.36 & 99.25 \\
\hline 12 & $\begin{array}{l}\text { Kapal melakukan sistem pemeliharaan berencana } \\
\text { yang mencakup prosedur pemeliharaan untuk } \\
\text { semua bagian dari sistem. }\end{array}$ & 4,38 & 4.52 & 96.79 \\
\hline 13 & $\begin{array}{l}\text { Perusahaan melakukan inspeksi untuk mengecek } \\
\text { pelaksanaan sistem pemeliharaan peralatan di } \\
\text { kapal. }\end{array}$ & 4,16 & 4.31 & 96.58 \\
\hline 14 & $\begin{array}{l}\text { Kapal mendata dan mendokumentasikan hasil } \\
\text { pemeriksaan dan pemeliharaan yang telah } \\
\text { dilakukan. }\end{array}$ & 4,27 & 4.33 & 98.54 \\
\hline 15 & $\begin{array}{l}\text { Kapal membuat laporan ke perusahaan } \\
\text { sehubungan dengan prosedur pemeliharaan dan } \\
\text { hasilnya. }\end{array}$ & 4,24 & 4.36 & 97.39 \\
\hline \multicolumn{5}{|c|}{ Perawatan dan perbaikan yang Berkelanjutan } \\
\hline 16 & $\begin{array}{l}\text { Perusahaan membuat dan mengembangkan } \\
\text { prosedur untuk mengawasi seluruh dokumen dan } \\
\text { data yang berkaitan dengan SMS. }\end{array}$ & 4,32 & 4.21 & 102.61 \\
\hline 17 & $\begin{array}{l}\text { Dokumen yang digunakan untuk pelaksanaan } \\
\text { SMS dijadikan referensi sebagai Buku Pedoman } \\
\text { Manajemen Keselamatan. }\end{array}$ & 4,41 & 4.50 & 97.90 \\
\hline 18 & $\begin{array}{l}\text { Dokumen kapal selain disimpan di kapal, } \\
\text { dokumen tersebut juga disimpan di kantor pusat/ } \\
\text { perusahaan. }\end{array}$ & 4,32 & 4.48 & 96.61 \\
\hline 19 & $\begin{array}{l}\text { Dokumen yang masih berlaku dan yang } \\
\text { kadaluarsa dipisahkan. }\end{array}$ & 4,32 & 4.33 & 99.79 \\
\hline 20 & $\begin{array}{l}\text { Pedoman Manajemen Keselamatan Kapal } \\
\text { diletakkan pada tempat yang dapat dibaca. }\end{array}$ & 4,54 & 4.55 & 99.84 \\
\hline & Rata-Rata & 4,42 & 4,48 & 98.68 \\
\hline
\end{tabular}


Tabel. 3 menunjukkan hasil nilai rata-rata antara kepentingan (importance) dan kinerja (performance). Sebagian besar faktor pada setiap aspek baik kinerja dan kepentingan memiliki nilai rata-rata lebih dari 4 dari skala 5 , yaitu 4,42 pada rata-rata kinerja atau kondisi, serta 4,48 pada rata-rata kepentingan atau harapan. Persentase pada tingkat kesesuaian menunjukkkan pencapaian kinerja dibandingkan dengan harapan. Semua faktor pada setiap aspek memiliki nilai persentase lebih dari $95 \%$, bahkan terdapat 2 faktor yang bernilai lebih dari $100 \%$. Tingginya persentase tersebut menunjukkan bahwa tingkat kinerja pada kondisi saat ini sudah mendekati tingkat kepentingan atau harapan. Selanjutnya, nilai rata-rata setiap faktor pada kinerja dan kepentingan digunakan untuk pemetaan dalam diagram yang terbagi menjadi 4 kuadran, sebagaimana ditunjukkan oleh Gambar. 4

Faktor dari keempat aspek Gambar. 4 terkait keselamatan kapal tergambar pada suatu diagram yang terbagi menjadi empat kuadran yang menunjukkan tingkat prioritas atas tindak lanjut yang diperlukan.Gambar 4 menunjukkan sebaran faktor kinerja pada kondisi yang dihadapi saat ini dengan kepentingan sebagai harapan dari para pengguna atau pelaku aktifitas.

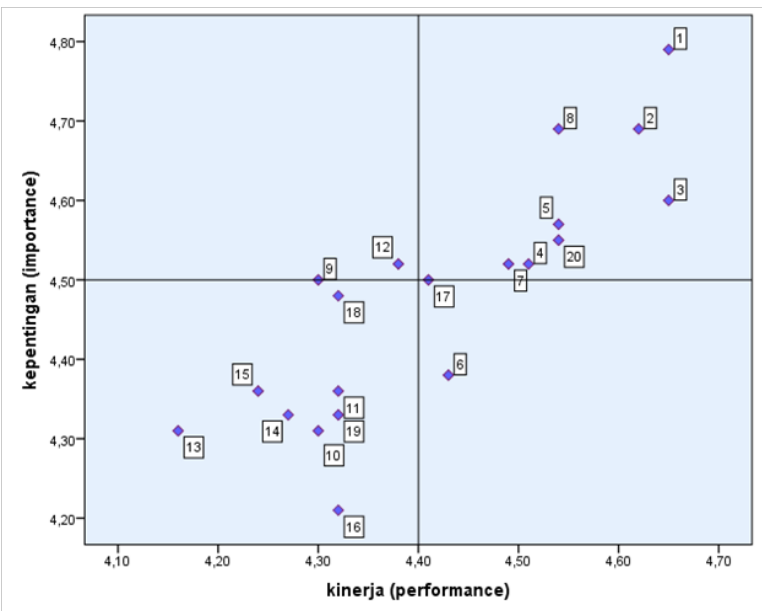

Gambar. 4 Diagram Analisis ImportancePerformance Keselamatan Kapal
- Kuadran 1: Keep Up The Good Work (Pertahankan Prestasi), kuadran ini menunjukkan faktor yang memiliki tingkat kinerja dan tingkat kepentingan tinggi. Faktor-faktor dalam kuadran ini harus tetap dipertahankan karena tingkat kinerjanya sesuai dengan tingkat kepentingan yang diharapkan oleh pihak-pihak terkait. Faktorfaktor yang masuk dalam kuadran 1 antara lain faktor nomor 1, 2, 3, 4, 5, 7, 8, 17 dan 20.

- Kuadran 2: Possible Overkill (Berlebihan), kuadran ini menunjukkan faktor yang memiliki tingkat kinerja tinggi tetapi tingkat kepentingan rendah. Faktor-faktor dalam kuadran ini dianggap kurang penting dan dirasakan terlalu berlebihan. Faktor-faktor yang termasuk dalam kuadran ini dapat dikurangi dengan alasan efisiensi. Faktorfaktor yang masuk dalam kuadran 2 antara lain faktor nomor 6 .

- Kuadran 3: Low Priority, (Prioritas Rendah), kuadran ini menunjukkan faktor yang memiliki tingkat kinerja dan tingkat kepentingan rendah. Kuadran ini memuat faktor-faktor yang dianggap kurang penting dan kinerjanya rendah. Peningkatan kualitas faktor-faktor yang termasuk dalam kuadran ini dapat dipertimbangkan kembali karena pengaruhnya terhadap manfaat yang dirasakan rendah. Faktor-faktor yang masuk dalam kuadran 2 antara lain faktor nomor 10, 11, 13, 14, 15, 16, 18 dan 19.

- Kuadran 4: Concentrate Here (Prioritas Utama), kuadran ini menunjukkan faktor yang memiliki tingkat kinerja rendah dan tingkat kepentingan tinggi. Kuadran ini memuat faktor-faktor yang dianggap penting, tetapi pada kenyataannya faktor-faktor ini belum sesuai dengan tingkat kepentingannya, sehingga faktor-faktor yang masuk dalam kuadran ini harus ditingkatkan. Faktorfaktor yang masuk dalam kuadran 4 antara lain faktor nomor 9 dan 12. Dengan hasil tersebut dapat dinyatakan bahwa factor 9 yaitu pelaksanaan drill/latihan untuk semua personil kapal dalam menunjang pelaksanaan SMS belum dilaksanakan secara penuh. Pelaksanaan Drill dari data wawancara 
yang peneliti lakukan diatas kapal hanya dilakukan diatas kertas berupa laporan rutin yang disampaikan untuk dokumentasi. Prakteknya pelaksanaan Drill/latihan tidak dilakukan diatas kapal. Hal ini tentu saja tidak sesuai dengan tujuan ISM Code yaitu Keselamatan jiwa di laut (Safety of Life at Sea - SOLAS), mencegah kecelakaan manusia dan hilangnya nyawa manusia, dan menghindari terjadinya kerusakan lingkungan dan properti (kapal, fasilitas pelabuhan, rambu-rambu navigasi dan muatan). Dengan pelaksanaan Dril/Latihan diatas kapal diharapkan crew kapal lebih siap dalam menghadapi keadaan darurat, memastikan kondisi peralatan keselamatan dan melatih kesigapan crew dalam keadaan darurat. Dan dari factor 12 yaitu sistem pemeliharaan berencana yang mencakup prosedur pemeliharaan untuk semua bagian dari system belum terlaksana dengan baik, data wawancara kami bahwa system pemeliharaan belum terintegrasi dengan baik, system pemeliharaan masih bersifat manual sehingga terkadang terdapat pemeliharaan yang tidak terencana dengan baik sehingga tidak dilaksanakan hal ini akan memperburuk apabila tidak segera ditangani karena akan mengakibat kerusakan alat yang lebih parah. Sehingga dari kedua factor yang ada pada kuadran 4 yaitu memiliki kondisi yang lemah dengan kepentingan yang tinggi perlu perhatian untuk ditingkatkan.

2). Pemahaman Officer terhadap Penerapan ISM Code di atas Kapal

Implementasi ISM Code dalam penelitian ini diawali dengan deskripsi dari persentase responden yang memahami standar keselamatan tersebut. ISM Code dalam penelitian ini meliputi 4 aspek yaitu kesesuaian dokumen, sasaran manjemen keselamatan di perusahaan, sumber daya dan personel serta pemeliharaan kapal dan peralatannya. Berdasarkan empat aspek tersebut, didapatkan pemahaman officer mengenai ISM Code melalui persentase responden yang dapat memberikan jawaban secara tepat. Persentase ketepatan jawaban atas pernyataan dari keempat aspek menunjukan pemahaman officer tentang ISM Code. Melalui survei dengan kuesioner didapatkan sejumlah 88 officer sebagai responden.

Aspek kesesuaian dokumen diamati melalui pendokumentasian perusahaan yang memuat kebijakan tentang keselamatan dan pencegahan pencemaran, pemberian sertifikat DOC kepada perusahaan yang telah memenuhi standar ISM Code, masa berlaku DOC dan SMC, pengertian SMC dan tanggung jawab nakhoda dalam menjalankan kegiatan sesuai ISM Code setelah kapal mendapatkan sertifikat. Berdasarkan hasil penelitian didapatkan bahwa, dari 88 responden, 80 orang memberikan jawaban yang tepat. Dari hal tersebut, dapat dinyatakan bahwa 90,91\% officer memahami pendokumentasian perusahaan yang memuat kebijakan tentang keselamatan dan pencegahan pencemaran. Sementara itu, dalam hal pemberian sertifikat DOC kepada perusahaan yang telah memenuhi standar ISM Code, terdapat $98,86 \%$ responden yang dapat memberikan jawaban secara tepat. Selanjutanya, untuk masa berlaku DOC dan SMC, pengertian SMC dan tanggung jawab nakhoda dalam menjalankan kegiatan sesuai ISM Code setelah kapal mendapatkan sertifikat didapatkan masing-masing 65,91\%, $100 \%$ dan $97,73 \%$.

Pada aspek sasaran manajemen keselamatan di perusahaan, hal yang diamati antara lain tujuan utama ISM Code, pelaporan kejadian kecelakaan kapal, tujuan kebijakan keselamatan dan perlindungan lingkungan, jaminan kekuatan peraturan dan hukum yan berlaku atas sistem manajemen keselamatan dan internal audit dalam sistem manajemen keselamatan. Hasil penelitian menunjukkan bahwa terdapat $22,73 \%, 89,77 \%, 100 \%$, 94,32 dan $50 \%$ responden yang memberikan jawaban secara tepat pada masing-masing faktor.

Untuk aspek sumber daya personil, terdiri dari tanggung jawab nakhoda terhadap pelaksanaan manajemen keselamatan, sifat kejujuran auditee, tanggung jawab ABK/ crew atas penerapan manajemen keselamatan, 
perilaku auditor dan berlakunya manajemen keselamatanbagi kapal berbendera Indonesia. Aspek Pemeliharaan kapal dan peralatannya meliputi kecukupan suku cadang saat perawatan dan perbaikan sehingga tidak kehilangan waktu operasi (down time), perbaikan atas kerusakan yang terpantau, prosedur perawatan kapal dan peralatannya dalam sistem manajemen keselamatan, prosedur menghadapi keadaan darurat terkait kesiapan, reaksi dan penganalisaan serta tanggung jawab crew/ABK terhadap semua alat keselamatan. Hasil persentase responden atas pernyataan dalam 4 aspek ISM Code ditunjukkan oleh Tabel. 4

Tabel. 4. Pemahaman Officer pada Implentasi ISM Code

\begin{tabular}{|c|c|c|}
\hline No. & PERNYATAAN & $\begin{array}{l}\text { PERSENTASE } \\
(\%)\end{array}$ \\
\hline \multicolumn{3}{|c|}{ Kesesuaian Dokumen } \\
\hline 1 & $\begin{array}{l}\text { Pendokumentasian perusahaan yang memuat kebijakan tentang } \\
\text { keselamatan dan pencegahan pencemaran }\end{array}$ & $90.91 \%$ \\
\hline 2 & $\begin{array}{l}\text { Pemberian sertifikat DOC kepada perusahaan yang telah memenuhi } \\
\text { standar ISM Code }\end{array}$ & $98.86 \%$ \\
\hline 3 & Masa berlaku DOC dan SMC & $65.91 \%$ \\
\hline 4 & Pengertian SMC & $100.00 \%$ \\
\hline 5 & $\begin{array}{l}\text { Tanggung jawab nakhoda dalam menjalankan kegiatan sesuai ISM } \\
\text { Code setelah kapal mendapatkan sertifikat. }\end{array}$ & $97.73 \%$ \\
\hline \multicolumn{3}{|c|}{ Sasaran Manajemen Keselamatan di Perusahaan } \\
\hline 6 & Tujuan utama ISM Code & $22.73 \%$ \\
\hline 7 & Pelaporan kejadian kecelakaan kapal & $89.77 \%$ \\
\hline 8 & Tujuan kebijakan keselamatan dan perlindungan lingkungan & $100.00 \%$ \\
\hline 9 & $\begin{array}{l}\text { Jaminan kekuatan peraturan dan hukum yan berlaku atas sistem } \\
\text { manajemen keselamatan }\end{array}$ & $94.32 \%$ \\
\hline 10 & Internal audit dalam sistem manajemen keselamatan & $50.00 \%$ \\
\hline \multicolumn{3}{|c|}{ Sumber Daya dan Personel } \\
\hline 11 & $\begin{array}{l}\text { Tanggung jawab nakhoda terhadap pelaksanaan manajemen } \\
\text { keselamatan }\end{array}$ & $6.82 \%$ \\
\hline 12 & Sifat kejujuran auditee & $75.00 \%$ \\
\hline 13 & Tanggung jawab ABK/crew atas penerapan manajemen keselamatan & $95.45 \%$ \\
\hline
\end{tabular}




\begin{tabular}{|c|l|c|}
\hline No. & \multicolumn{1}{|c|}{ PERNYATAAN } & $\begin{array}{c}\text { PERSENTASE } \\
(\%)\end{array}$ \\
\hline 14 & Perilaku auditor & $61.36 \%$ \\
\hline 15 & Berlakunya manajemen keselamatan bagi kapal berbendera Indonesia & $92.05 \%$ \\
\hline Pemeliharaan Kapal dan Peralatannya & $89.77 \%$ \\
\hline 16 & $\begin{array}{l}\text { Kecukupan suku cadang saat perawatan dan perbaikan sehingga tidak } \\
\text { kehilangan waktu operasi (down time) }\end{array}$ & $75.00 \%$ \\
\hline 17 & $\begin{array}{l}\text { Perbaikan atas kerusakan yang terpantau } \\
18\end{array}$ & $\begin{array}{l}\text { Prosedur perawatan kapal dan peralatannya dalam sistem manajemen } \\
\text { keselamatan }\end{array}$ \\
\hline 19 & $\begin{array}{l}\text { Prosedur menghadapi keadaan darurat terkait kesiapan, reaksi dan } \\
\text { penganalisaan }\end{array}$ & $80.68 \%$ \\
\hline 20 & \begin{tabular}{l} 
Tanggung jawab crew/ABK terhadap semua alat keselamatan \\
\hline
\end{tabular} & $82.95 \%$ \\
\hline
\end{tabular}

Tabel. 4 menunjukkan bahwa $100 \%$ responden dapat memahami faktor terkait SMC (Safety Management Certificate) dan tujuan kebijakan keselamatan dan perlindungan lingkungan. Hal tersebut mengidikasikan bahwa Safety Management Certificate (SMC) dan tujuan kebijakan keselamatan dan perlindungan lingkungan telah dipahami oleh para officer kapal. Nilai persentase rendah ditunjukkan oleh faktor tanggung jawab nakhoda terhadap pelaksanaan manajemen keselamatan dan tujuan utama ISM Code. Pada pernyataan tanggung jawab nakhoda terhadap pelaksanaan manajemen keselamatan hanya $6,82 \%$ responden yang memberikan jawaban secara tepat, sedangkan pada faktor tujuan utama ISM Code terdapat 22,73\% yang memahami tujuan ISM Code. Perlu dipahami bahwa pelaksanaan manajemen keselamatan bukan hanya tanggung jawab nakhoda, dan tujuan utama ISM Code bukan untuk menetapkan standar mutu perusahaan sebagaimana disebutkan dalam pernyataan kuesioner.
B. Pemahaman Crew kapal tentang ISM Code

Dalam penelitian ini juga ingin diketahui sejauh mana implementasi ISM Code melalui pengetahuan yang dimiliki oleh kru kapal terkait hal tersebut. Penelitian dilakukan melalui pemberian kuesioner pada kru yang berisi pertanyaan beserta empat opsi jawaban. Selanjutnya dilakukan rekapitulasi berupa persentase kru kapal yang memberikan jawaban secara tepat. Pada bagian ini, kru kapal diberikan pertanyaan mendasar terkait ISM Code. Dalam survei ini didapatkan sejumlah 155 orang kru kapal sebagai responden. Hasil rekapitulasi persentase responden ditunjukkan oleh Tabel 5.

Tabel 5 menunjukkan persentase kru kapal yang memiliki ketepatan jawaban diantara 155 orang responden. Dapat diambil contoh untuk pertanyaan terkait ISM Code, terdapat $83,87 \%$ kru kapal yang dapat memberikan jawaban yang sesuai. Berdasarkan Tabel 5 didapatkan bahwa terdapat beberapa butir pertanyaan yang mendapatkan nilai persentase yang rendah, yaitu pada butir-butir diantaranya Tanggung 
Tabel 5. Pemahaman dan Pengetahuan Kru tentang ISM Code

\begin{tabular}{|c|c|c|}
\hline $\mathrm{NO}$ & URAIAN & $\begin{array}{l}\text { PERSENTASE } \\
(\%)\end{array}$ \\
\hline 1 & Pengertian ISM Code & $83.87 \%$ \\
\hline 2 & Kepanjangan dari DPA & $80.65 \%$ \\
\hline 3 & Tanggung jawab DPA Koordinasi evaluasi kecelakaan & $14.84 \%$ \\
\hline 4 & tanggung jawab dari DPA Koordinasi kendali dokumen SMS & $17.42 \%$ \\
\hline 5 & tanggung jawab dari monitoring safety drill dan safety meeting & $76.77 \%$ \\
\hline 6 & tanggung jawab dari fungsi armada & $20.65 \%$ \\
\hline 7 & tanggung jawab dari fungsi crewing / personalia & $39.35 \%$ \\
\hline 8 & tanggung jawab dari fungsi logistik & $68.39 \%$ \\
\hline 9 & tanggung jawab dari seorang nahkoda & $14.84 \%$ \\
\hline 10 & Hal yang tidak berkaitan dengan keselamatan & $83.87 \%$ \\
\hline 11 & Hal yang ingin dicapai dari PSC dalam pelayaran & $75.48 \%$ \\
\hline 12 & $\begin{array}{l}\text { pedoman yang harus diperhatikan dalam inspeksi pengawasan kapal } \\
\text { asing }\end{array}$ & $85.16 \%$ \\
\hline 13 & Indikasi yang terdapat dalam kapal substandar & $63.87 \%$ \\
\hline 14 & lingkup pemerikaan dalam PSC & $61.94 \%$ \\
\hline 15 & maksud dengan kapal sub standar & $76.77 \%$ \\
\hline 16 & Maksud dari penahanan (detention)? & $43.23 \%$ \\
\hline 17 & Hal yang bukan Lingkup dari pemeriksaan PSC adalah.Colreg 72 & $70.32 \%$ \\
\hline 18 & Aturan konvensi untuk mengetahui berlakunya sertifikat & $23.23 \%$ \\
\hline 19 & Penyelidikan dalam PSCO & $58.06 \%$ \\
\hline \multirow[t]{2}{*}{20} & Wewenang dan tanggung jawab nakhoda & $25.81 \%$ \\
\hline & Rata-rata & $54.23 \%$ \\
\hline
\end{tabular}


jawab DPA Koordinasi evaluasi kecelakaan, tanggung jawab dari DPA Koordinasi kendali dokumen SMS, tanggung jawab dari fungsi armada, tanggung jawab dari fungsi crewing / personalia, tanggung jawab dari seorang nahkoda, serta aturan konvensi untuk mengetahui berlakunya sertifikat. Namun demikian, beberapa hal yang memiliki persentase tinggi menunjukkan bahwa kru kapal memahami tentang pengertian ISM Code, kepanjangan dari DPA, tanggung jawab dari monitoring safety drill dan safety meeting, hal yang berkaitan dengan keselamatan, hal yang ingin dicapai dari PSC dalam pelayaran dan pedoman yang harus diperhatikan dalam inspeksi pengawasan kapal asing. Secara umum dapat dinyatakan bahwa pemahaman kru kapal tentang ISM Code termasuk dalam kategori kurang, yang ditunjukkan oleh nilai persentase sebesar $54,23 \%$. Persentase tersebut menunjukkan bahwa terdapat 54,23\% responden yang memberikan jawaban secara tepat.

\section{KESIMPULAN}

Simpulan yang didapatkan dari penelitian ini diantaranya adalah

1. Implementasi ISM Code pada kapal-kapal di Pelabuhan Tanjung Perak menunjukkan bahwa terdapat faktor-faktor yang perlu mendapatkan perhatian dan peningkatan yaitu pelaksanaan drill/latihan untuk semua personil kapal dalam menunjang pelaksanaan SMS dan sistem pemeliharaan berencana yang mencakup prosedur pemeliharaan untuk semua bagian dari sistem. Implementasi ISM Code yang diamati dari pemahaman Officer menunjukkan bahwa secara umum termasuk dalam kategori baik, dimana sebanyak 77,33 $\%$ responden memberikan jawaban dengan benar.
2. Tingkat pemahaman dan pengetahuan crew tentang ISM Code termasuk dalam kategori kurang dimana terdapat $54,23 \%$ responden dapat memberikan jawaban dengan tepat.

\section{DAFTAR PUSTAKA}

[1] Dephub 2008. Undang - Undang RI Nomor 17 Tahun 2008 tentang Pelayaran, Dephub Biro Hukum dan KSLN

[2] Departemen Perhubungan Laut, Keputusan Direktur Jenderal Perhubungan Laut Nomor : PY.66/I/4-03 tentang Tata Cara Tetap Pelaksanaan Penyelenggaraan Kelaiklautan Kapal dan Pengawasan/Pemeriksaan tentang Nautis, Tekni, Radio dan Peralatan Pencegahan Pencemaran (OWS,AOD), Pengawasan Keselamatan Kapal

[3] Direktorat Jenderal Perhubungan Laut, 1993 . Suatu Bahasan tentang Komfrensi Internasional IMO, tentang :

Prevention of Pollution from Ships, 1973, as midified by the protocol of 1978 (Marpol, 73/78), Safety of Life at Sea, 1974, and Its Protocol of 1988 (Solas, 74/78), Seafarer's Traning Certification and Watch Keeping, 1995 Amandemen 1997 (STCW Code 95, 79), International Safety Management Code (ISM Code Tahun 1994, Resolusi IMO No. A. 741 (18 Tahun 1993)

[4] Bittel, M.A., and Bittel, L.R. (1978). Encyclopedia of profesional management. Danbury, Connecticut: Grolier International.

[5] Handoko. 2000. Manajemen Sumber Daya Manusia. Jakarta: Balai Pustaka

[6] Moenir. 1992. Manajemen Pelayanan Umum. Jakarta: Haji Musary

[7] Paemboban A.R. 1994. Analisis Tentang Koordinasi Pengelolaan Lingkungan Hidup (studi Kasus di Kabupaten Tana Toraja). Disertasi Program Pascasarjana IPB. Unhas 